\title{
In vitro evaluation of pomegranate (Punica granatum L.) peels antibacterial activity against bacteria responsible of diabetic foot infections
}

\author{
Leila Bouneb ${ }^{2}$, Zohra Chekroud ${ }^{1,2 *}$, Ibtihedj Souda², Zoulikha Ouchenane ${ }^{3}$ \\ ${ }^{1}$ Research Laboratory of Interactions of Biodiversity, Ecosystems and Biotechnology, University of August 20 ${ }^{\text {th }}$, 1955, \\ Skikda, Algeria \\ ${ }^{2}$ Department of Sciences of Life and of Nature, Faculty of Sciences, University of August 20 ${ }^{\text {th }}$, 1955, Skikda, Algeria \\ ${ }^{3}$ Regional Military and University Hospital Abdelali Benbaatouch, Constantine, Algeria
}

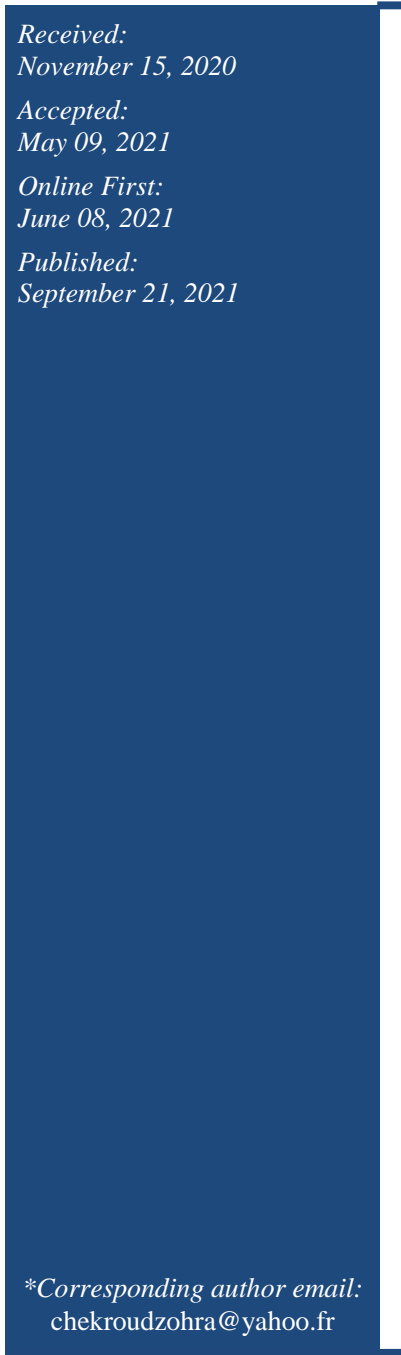

\begin{abstract}
Diabetic foot infections are common complications of diabetes. Antibioresistant bacteria are associated with a higher incidence of lower-limb amputation. Punica granatum $\mathrm{L}$. is one of the plants used by many civilisations in the treatment of infectious maladies. Our work consists of evaluating in vitro the antibacterial activity of three extracts of pomegranate peels on Gram positive and Gram negative bacterial strains isolated from diabetic foots pus. The active molecules were obtained by maceration of pomegranate peel powder in ethanol/water (30/70) and fractionation using three solvents: dichloromethane (EDCM), ethyl acetate (EEA) and the n-Butanol $(\mathrm{En}-\mathrm{BuOH})$. The bacterial susceptibility to the extracts was determined using the disks diffusion test and the Minimal Inhibitory Concentration (MIC) by dilution in liquid medium using sterile microplates. The three extracts were active against the tested strains with maximum activity of the extract $(\mathrm{En}-\mathrm{BuOH})$ against Staphylococcus epidermidis $(35.3 \pm 0.3 \mathrm{~mm})$. Enterobacter aerogenes was less sensitive to the extracts

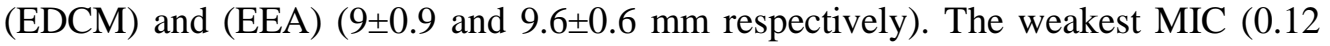
$\mathrm{mg} / \mathrm{ml}$ ) was recorded within Morganilla morganii with the three fractions and within Proteus mirabilis with the fraction ethyl acetate. Furthermore, the highest MIC (> 250 $\mathrm{mg} / \mathrm{ml}$ ) was fond within Staphylococcus aureus and Enterobacter aerugenes with dichloromethane, Escherichia coli and Pseudomonas aeruginosa with different fractions. More of that, the extracts were characterised by an antibacterial activity better than some used antibiotics to whom the strains were multiresistant.
\end{abstract}

Keywords: Antibacterial activity, Diabetic foot, Minimal inhibitory concentration, Punica granatum L.

How to cite this:

Bouneb L, Chekroud Z, Souda I, and Ouchenane Z, 2021. In vitro evaluation of pomegranate (Punica granatum L.) peels antibacterial activity against bacteria responsible of diabetic foot infections. Asian J. Agric. Biol. 2021(4): 202011556. DOI: https://doi.org/10.35495/ajab.2020.11.556

This is an Open Access article distributed under the terms of the Creative Commons Attribution 3.0 License. (https://creativecommons.org/licenses/by/3.0), which permits unrestricted use, distribution, and reproduction in any medium, provided the original work is properly cited.

\section{Introduction}

Diabetes has become an increasingly prevalent and severe public health issue in Algeria. The national evidence suggests that the prevalence of diabetes in Algeria has increased from $6.8 \%$ in 1990 to $12.29 \%$ in 
2005 (Lamri et al., 2014). Algeria is particularly impacted by the epidemic to the point of appearing in the "top 10" 2016 of countries with very high incidence of T1D (Touhami et al., 2019). Foot problems in diabetes are common and costly, and people with diabetes make up about half of all hospital admissions for amputations (Boulton et al., 2018). Among patients with diabetes presenting with a foot wound, about half have clinical evidence of infection (Lipsky et al., 2016). For people with diabetes, DFIs are the most common diabetes-related reason for hospitalizations and for lower extremity amputations (Boulton et al., 2018). This is due to the disruption of the protective skin. The deformed foot becomes colonised with infectious bacteria (Fisher et al., 2010). Gram cocci bacteria and specially Staphylococcus aureus are the most isolated germs from DFI infections (Lipsky et al., 2012; Citron et al., 2007; Roberts and Simon, 2012). Antibiotics are one of the mainstays of treating diabetic foot infections. Drug-resistant organisms are over-represented in samples obtained from diabetic foot ulcers (Powlson and Coll , 2010) and are associated with a higher incidence of lower-limb amputation (Richard, 2008). Plants are prospective source of antimicrobial agents in different countries (Alviano and Alviano, 2009). Punica granatum L. (pomegranate) is one of the plants arousing interest for its virtues medicinal. Their Peel have been commonly employed as a crude drug in traditional medicine for the treatment of diarrhea as well as for use as an astringent, antihelminthic, asphrodisacs, laxative, diuretic, stomachic, cardiotonic and refrigerant (Pradeep et al., 2008). Therefore, our objective is firstly to confirm In Vitro the antibacterial activity of the pomegranate peel extracts (En-BuOH, EDCM and EEA) against multiresistant bacteria isolated from diabetic foot ulcers and secondly to ameliorate the costs of diabetic foot infections treatment by substituting the classical antibiotics by the tested extracts or conjugating the two treatments and this to limit the rate of lower-limb amputation.

\section{Material and Methods}

Our work consists of three parts; extraction of active molecules from grenade peel, isolation of bacterial strains from infected diabetic foot and testing the effect of the extracted active molecules on the isolated bacterial strains.

\section{Sampling and macroscopic exams}

The method of sampling depends on the infection level, superficial or deep. When samples are quite abundant, macroscopic exams may provide interesting information: a bad smell pus for the anaerobic bacteria, granular aspect for streptococci and creamy aspect for staphylococci or pneumococci.

\section{Cytologic exam}

It consists of counting the number of polynuclear and neutrophil cells as well as the presence and absence of germs by the methods of Hanging-drop. The methods of simple coloration using methylene blue and Gram coloration determine the form, the size and the regrouping mode of the bacterial cells. They are indicative exams for the choice of the culture media.

\section{Bacteriological exams}

The isolation of bacterial strains was done by culturing pus directly in three media: Chapman, Hektoen and Blood agar. In case of negative culture the previously enriched pus in brain heart infusion broth ( BHIB) or in glucose buffered broth medium was used. Enterobacteria were identified by the biochemical miniaturised kits (API 20E). Staphylococci strains were identified according to the presence and absence of the catalase and coagulase enzymes. Two reference strains were also used, Escherichia coli ATCC25922 and Staphylococcus aureus ATCC29213.

\section{Preparation of the three extracts}

The pomegranate fruit (Punica granatum L.) was obtained from Ramdan Djamel town, the state of Skikda during the month of October 2015. The fruit peel was then isolated and dried at the temperature room, in the darkness and grinded. The obtained powder was used to prepare the different extracts.

\section{Maceration}

The method of Merghem et al. (1995) was used with modification of the used solvents. The pomegranate peel powder $(200 \mathrm{~g})$ was added to ethanol/water (30/70) v/v. The mixture was well shacked during $72 \mathrm{~h}$ with renewal of the mixture each $24 \mathrm{~h}$.

\section{Extraction liquid/liquid}

The macerates were reunited and filtered by filter paper. The recovered filtrate was then evaporated using a rotary evaporator. The dry residue was recuperated in $200 \mathrm{ml}$ boiling distilled water. The extract was then decanted during a night and the 
limpid phase underwent fractionation using three solvents with increasing polarity: dichloromethane (EDCM), ethyl acetate (EAA) and the n-butanol (En$\mathrm{BuOH})$. The aqueous phase and the solvent were well agitated and left to rest for 30 minutes. The aqueous phase in the bottom of the separating funnel and the phase charged with active molecules were recovered separately. The active phase charged with polyphenols was dried and the following equation was used for the determination of the extraction yield (Harborne, 1998): Yield= (weight of the extract / weight of the vegetal material) $* 100$.

\section{Determination of antibacterial activity of pomegranate peel extracts}

Antibacterial susceptibility to pomegranate peel extracts was tested using agar disks diffusion technique. Stock solutions of the three tested extracts were prepare by diluting each dried extract in dimethyl sulfoxide (DMSO) to obtain a final concentration of $250 \mathrm{mg} / \mathrm{ml}$. Muller Hinton medium was aseptically poured into sterile Petri plates. The bacterial inoculums (300Ul) adjusted to $0.5 \mathrm{Mac}$ Farland $\left(10^{8}\right.$ Cells/ml) (CA-SFM, 2012) and diluted to $1 / 10\left(10^{7}\right.$ cells/ml) (CA-SFM, 2010) was swabbed on MullerHinton medium. $6 \mathrm{~mm}$ filter paper disks loaded into 10ul of the tested extract were placed on the plates at equivalent interval. A pure DMSO loaded disk was added as a negative control. The cultures were left 15 minutes for a pre-diffusion before they were incubated at $37^{\circ} \mathrm{C}$ for 24 hours. The experiment was realised in triplicate and mean value of zone inhibitions was calculated. The bacterial sensitivity toward the extracts was classified according to Moreira et al. (2005): $8 \leq \mathrm{mm}$ : Not sensitive (-), 9-14 mm: Sensitive (+), 15-19 $\mathrm{mm}$ : Very sensitive $(++), \geq 20 \mathrm{~mm}$ : Extremely sensitive $(+++)$

\section{Evaluation of minimal inhibitory concentration (MIC) in liquid medium:}

The minimal inhibitory concentration was determined using sterile microplates ( $8 \times 12$ wells). $0.1 \mathrm{ml}$ of nutrient broth were added to the wells of the same line, then 0.1 of the tested extract $(250 \mathrm{mg} / \mathrm{ml})$ were added to the first well and well homogenized with nutrient broth. $0.1 \mathrm{ml}$ of the mixture were transferred from well to well to obtain dilutions at a factor of $1 / 2$. Finally, $0.1 \mathrm{ml}$ of the inoculums previously diluted to $1 / 100$ $\left(10^{6}\right.$ cells $\left./ \mathrm{ml}\right)$ were added to each well (EUCAST, 2003). Thereby, the concentration $250 \mathrm{mg} / \mathrm{ml}$ was diluted successively to $1 / 2,1 / 4,1 / 8,1 / 16,1 / 32,1 / 64$,
$1 / 128,1 / 156,1 / 512,1 / 1024$ and $1 / 2048$. The plates were incubated at $37^{\circ} \mathrm{C}$ for 24 hours. The MIC was determined by the concentration where no trouble was observed.

\section{Antibiogram}

Antibacterial susceptibility to the tested antibiotics was determined based on the directives of CA-SFM (2010). A bacterial suspension of 0.5 Mac Farland was previously prepared. Muller Hinton medium poured into Petri plates was seeded by swabbing the swab onto its surface to achieve tight steaks. The antibiotics disks were placed on the surface of the medium and the plates were incubated at $37^{\circ} \mathrm{C}$ for $16-24$ hours (CA-SFM, 2010). The obtained inhibition zones around the antibiotics were measured and the bacterial strains were classified as sensitive (S) or resistant (R) (CA-SFM, 2012).

\section{Statistical analysis}

Inhibition zones were done in triplicate sets and the results were expressed in mean value \pm SD (Steel et al., 1995)

\section{Results and Discussion}

\section{Bacterial strains}

Eight bacterial strains were isolated from diabetic foots: Proteus mirabilis, Pseudomonas aeruginosa, Morganella morganii, Enterobacter aerogenes, Enterobacter cloacae, Escherichia coli, Staphylococcus epidermidis and Staphylococcus aureus. Two reference strains Escherichia coli ATCC25922 and Staphylococcus aureus ATCC29213 provided by Pasteur institute of Algeria were also tested. Enterobacteria strains were identified using their macroscopic, microscopic and biochemical characters (Table1). Staphylococcus aureus was Catalase and Coagulase positive however Staphylococcus epidermidis was Catalase positive and Coagulase negative.

\section{Yield of polyphenols extraction}

Three fractions were obtained, dichloromethane fraction $(\mathrm{EDCM})$, n-butanol fraction $(\mathrm{En}-\mathrm{BuOH})$ and ethyl acetate fraction (EEA). The best yield of extraction was obtained with En-BuOH (3.27\%) followed by EEA $(0.25 \%)$ and finally $\operatorname{EDCM}(0.20 \%)$. Sajjad et al. (2015) showed that the yield of Punica granatum L. ethyl acetate extract was $6 \%$ whereas the 
ethanolic extract yield was 3\%. Our yields were less than that of the methanolic extract tested by Sultana et al. (2008) (16.4\%). These variations depend on the phytochemistry of different pomegranate extracts (ElFalleh et al., 2012). The composition of pomegranate peel depends on many environmental factors, processing, cultivar and post harvesting (Houston, 2005)

Table-1. Biochemical characters of selected Gram negative bacteria.

\begin{tabular}{|c|c|c|c|c|c|c|c|}
\hline & $\begin{array}{c}P . \\
\text { mirabilis }\end{array}$ & $\begin{array}{c}P . \\
\text { aeruginosa }\end{array}$ & $\begin{array}{c}M . \\
\text { morganii }\end{array}$ & $\begin{array}{c}E . \\
\text { aerogenes }\end{array}$ & $\begin{array}{c}E . \\
\text { cloacae }\end{array}$ & E. coli \\
\hline \multirow{13}{*}{ 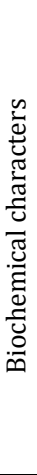 } & Glucose & + & + & + & + & + & + \\
\hline & Lactose & - & - & - & + & - & + \\
\hline & Saccharose & + & - & - & + & + & + \\
\hline & $\mathrm{H}_{2} \mathrm{~S}$ & + & - & - & - & - & - \\
\hline & Gaz & + & - & - & + & + & + \\
\hline & $\begin{array}{l}\text { Simons } \\
\text { Citrate }\end{array}$ & + & + & - & + & + & - \\
\hline & Mannitol & - & - & - & + & + & + \\
\hline & Mobilité & + & + & + & + & + & + \\
\hline & Urease & + & + & + & - & - & - \\
\hline & Indole & - & - & + & - & - & + \\
\hline & L.D.C & - & - & - & + & - & + \\
\hline & O.D.C & + & - & + & + & + & + \\
\hline & A.D.H & + & + & - & - & + & - \\
\hline & & & t: Positive & - :Negat & & & \\
\hline
\end{tabular}

\section{Antibacterial activity of the three extracts}

The obtained results (Table 2 and Figure 1) showed that the three fractions of pomegranate peel were active against the eight strains. This activity indicates the presence of toxic secondary metabolites towards the tested strains (Voravuthikunchai et al., 2004). Pomegranate is known as a rich source of pharmacological properties which have been evaluated due to antiparasitic, antibacterial, antifungal antiproliferative, apoptotic and anti-cancer effects (Reddy et al., 2007; Kim et al., 2002; Naz et al., 2007). The inhibition zones vary according to the used extract and the tested strain. The comparison of the average of three inhibition zones replicates revealed that the highest antibacterial activity was recorded against Staphylococcus aureus and Staphylococcus epidermidis as well as Staphylococcus aureus ATCC29213 with the three extracts (29.3 \pm 0.3 $35.3 \pm 0.3 \mathrm{~mm}$ ) and against Morganella morganii and Proteus mirabilis with En-BuOH and EEA (21 $\pm 0.6-$ $22.6 \pm 0.6 \mathrm{~mm})$. Moderate inhibition zones were observed against Escherichia coli ATCC 25922 within the three extracts $(14.6 \pm 0.3-17 \pm 07 \mathrm{~mm})$ as well as Pseudomonas aeuginosa, Enterobacter cloacae and Morganella morganii within En-BuOH, EEA and EDCM respectively (14.6 $\pm 0.2-18.3 \pm 0.3 \mathrm{~mm})$. Escherichia coli and Enterobacter aerugenes were less sensitive to EEA and EDCM fractions (9 \pm 0.9 $12 \pm 0.2 \mathrm{~mm})$ as well as Proteus mirabilis and Pseudomonas aeruginosa with EDCM (11.6 \pm 0.6 $13.3 \pm 0.3 \mathrm{~mm})$. Gram negative bacteria were less sensitive in comparison with Gram positive bacteria. The outer membrane of Gram negative bacteria high in polysaccharides prevents certain antibacterial biomolecules from entering into the cell (Bagamboula et al., 2004). Our results corroborate those of Reddy et al. (2007) and those of Celia and Jenifer (2018) who demonstrated that the pomegranate peel extracts constitute a very strong inhibitor of Staphylococcus aureus growth (Inhibition zones $>20 \mathrm{~mm}$ ). Hence, the antibacterial activity of Punica granatum L. may be related to polyphenol structures (Rathia et al., 2014; Barathikannan et al., 2016) because polyphenols may affect the bacterial cell wall, inhibit enzymes by oxidized agents, interact with proteins and disturb co-aggregation of microorganisms (Naz et al., 2007; Vasconcelos et al., 2003).

Table-2. Bacterial strains sensitivity towards the three pomegranate peel extracts

\begin{tabular}{|c|c|c|c|c|c|c|c|c|c|c|}
\hline $\begin{array}{c}\text { Bacterial } \\
\text { strains } \\
\text { Inhibition } \\
\text { zones(mm) } \\
\end{array}$ & $\begin{array}{c}\text { S.aureus } \\
\text { ATCC29213 }\end{array}$ & S.aureus & $\begin{array}{c}\text { Staphylococcus } \\
\text { epidermidis }\end{array}$ & \begin{tabular}{c|} 
E.coli \\
ATCC25922
\end{tabular} & E.coli & $\begin{array}{c}\text { Enterobacter } \\
\text { aerogenes }\end{array}$ & $\begin{array}{c}\text { Enterobacter } \\
\text { Cloacae }\end{array}$ & $\begin{array}{c}\text { Morganella } \\
\text { Morganii }\end{array}$ & $\begin{array}{c}\text { Pseudomonas } \\
\text { aeruginosa }\end{array}$ & $\begin{array}{l}\text { Proteus } \\
\text { mirabilis }\end{array}$ \\
\hline n- butanol & $32.3 \pm 0.3$ & $32.6 \pm 0.6$ & $35.3 \pm 0.3$ & $17 \pm 07$ & $11.6 \pm 0.6$ & & $12.3 \pm 0.6$ & & $17 \pm 0.7$ & $21 \pm 0.6$ \\
\hline Ethyl acetate & $31.6 \pm 0.2$ & $29.3 \pm 0.3$ & $33.6 \pm 0.2$ & $15.5 \pm 0.2$ & $10 \pm 0.2$ & $9.6 \pm 0.6$ & $15.6 \pm 0.2$ & $22.6 \pm 0.6$ & $14.6 \pm 0.2$ & $21.3 \pm 0.3$ \\
\hline Dicloromethane & $30.3 \pm 0.2$ & $29.6 \pm 0.3$ & $33.6 \pm 0.2$ & $14.6 \pm 0.3$ & $12 \pm 0.2$ & $9 \pm 0.9$ & $10.3 \pm 0.3$ & $18.3 \pm 0.3$ & $11 \pm 0.7$ & $13.3 \pm 0.3$ \\
\hline
\end{tabular}

$8 \leq \mathrm{mm}$ : Not sensitive (-), 9-14 mm: Sensitive (+), 15-19 mm: Very sensitive (++), $\geq 20 \mathrm{~mm}$ : Extremely sensitive $(+++)$. (Moreira et al., 2005) 


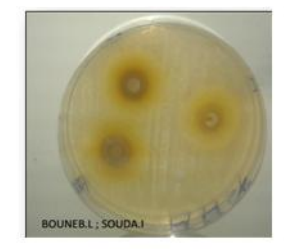

Staphylococcus epidermidis

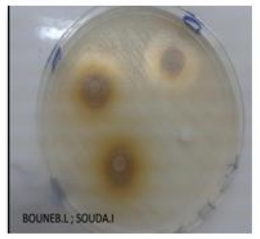

Staphylococcus aureus
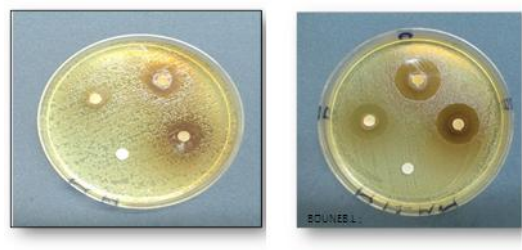

Morganella morganit

Proteus mirabilis

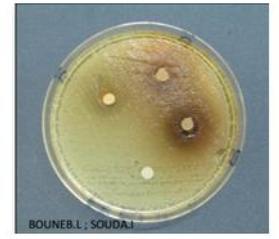

Escherichia coli

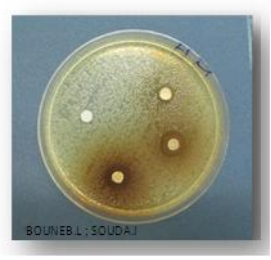

Enterobacter cloacae

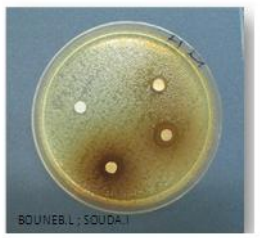

Enterobacter aerogenes

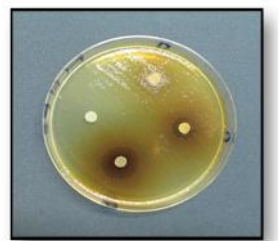

Pseudomonas aeruginosa

Figure-1. Inhibition zones of the three extracts EnBuOH, EAA and EDCM against the tested bacterial strains

\section{Comparison of antibacterial activity of antibiotics} and pomegranate peel extracts

Enterobacteria strains: Escherichia coli, Morganella morganii and Enterobacter aerugenes are multiresistant bacteria (Table 3). They were resistant to three antibiotics families (B-Lactamines, Polymixines and Aminoglygosides). They were on the other hand sensitive to the three tested extracts with inhibition zones varying from 9 $\pm 0.9-21.6 \pm 0.0 \mathrm{~mm}$ (Table2). Pradeep et al. (2008) and Khan and Hanee (2011) demonstrated that the tested E.coli was more sensitive to Tetracyclin, Viprofloxacin and Oflaxacin in comparison with the tested extracts. Proteus mirabilis and Escherichia coli ATCC259 were however sensitive to the tested antibiotics as well as the tested extracts (13.3 $\pm 0.3-21.3 \pm 0.3)$.

Pseudomonas aeruginosa which is a multi resistant strain to more than three antibiotics families (BLactamines, Quinolones, Aminosides, Tetracyclines and Fosfomycines) (Table 4) was very sensitive to the extract En-BuOH $(17 \pm 0.7 \mathrm{~mm})$ and sensitive to EEA $(14.6 \pm 0.2 \mathrm{~mm})$ and EDCM $(11 \pm 0.7 \mathrm{~mm})$. These values are superior of that obtained by Belaidi (2012) and

Pradeep et al. (2008) as well as those of Sajjad et al. (2015) with ethyl acetate extract. They were on the other hand inferior of that obtained by Khan and Hanee (2011). This is due to the differences in the solubility of active molecules in each used solvent.

The tested Gram positive bacteria, Staphylococcus aureus, Staphylococcus epidermidis and Staphylococcus aureus ATCC29213 were highly sensitive to the tested extracts $(29.3 \pm 0.3-35.3 \pm 0.3 \mathrm{~mm})$ (Table 2).

Table-3. Antibiogram results of the tested Enterobacteria

\begin{tabular}{|c|c|c|c|c|c|c|}
\hline 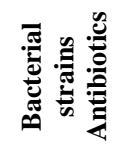 & 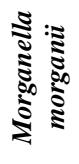 & 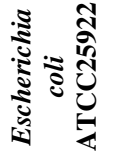 & 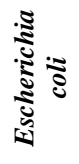 & 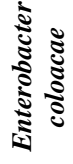 & 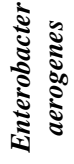 & 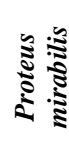 \\
\hline AM & $\mathrm{R}$ & $\mathrm{S}$ & $\mathrm{R}$ & $\mathrm{R}$ & $\mathrm{R}$ & $\mathrm{S}$ \\
\hline AMC & $S$ & $\mathrm{~S}$ & $\mathrm{R}$ & $\mathrm{R}$ & $\mathrm{R}$ & $S$ \\
\hline AMX & $\mathrm{R}$ & $\mathrm{S}$ & $\mathrm{R}$ & $\mathrm{R}$ & 1 & $\mathrm{R}$ \\
\hline CIP & $\mathrm{S}$ & $S$ & $\mathrm{R}$ & $\mathrm{R}$ & $\mathrm{S}$ & $\mathrm{S}$ \\
\hline $\mathrm{CRO}$ & $\mathrm{S}$ & $\mathrm{S}$ & $\mathrm{R}$ & $\mathrm{R}$ & $\mathrm{S}$ & S \\
\hline CTX & $\mathrm{R}$ & $\mathrm{S}$ & $\mathrm{R}$ & $\mathrm{R}$ & $\mathrm{S}$ & $\mathrm{R}$ \\
\hline IPM & $\mathrm{S}$ & $\mathrm{S}$ & $\mathrm{S}$ & $\mathrm{R}$ & $\mathrm{S}$ & S \\
\hline TIC & $\mathrm{S}$ & $\mathrm{S}$ & $\mathrm{R}$ & $\mathrm{R}$ & $\mathrm{R}$ & $\mathrm{S}$ \\
\hline $\mathrm{CZ}$ & $\mathrm{R}$ & $\mathrm{S}$ & $\mathrm{R}$ & $\mathrm{R}$ & $\mathrm{R}$ & $\mathrm{S}$ \\
\hline $\mathrm{AK}$ & $\mathrm{S}$ & $\mathrm{S}$ & $\mathrm{S}$ & $\mathrm{R}$ & 1 & $\mathrm{~S}$ \\
\hline GEN & $\mathrm{S}$ & $\mathrm{S}$ & $\mathrm{R}$ & $\mathrm{R}$ & $\mathrm{R}$ & S \\
\hline FOS & $S$ & $\mathrm{~S}$ & 1 & $\mathrm{R}$ & $\mathrm{S}$ & $\mathrm{S}$ \\
\hline CT & $\mathrm{R}$ & $\mathrm{S}$ & $\mathrm{S}$ & $\mathrm{R}$ & $\mathrm{R}$ & $\mathrm{S}$ \\
\hline TMP & 1 & 1 & 1 & $\mathrm{~S}$ & 1 & 1 \\
\hline En-BuOH & +++ & ++ & + & + & ++ & +++ \\
\hline EEA & +++ & ++ & + & ++ & + & +++ \\
\hline EDCM & ++ & ++ & + & + & + & + \\
\hline
\end{tabular}

S: sensitive, R: resistant (CA-SFM, 2012) ; + : sensitive $(9-14 \mathrm{~mm}),++$ : very sensitive (15 -19 $\mathrm{mm}),+++$ : extremely sensitive $(>20 \mathrm{~mm})$ (Moreira et al., 2005).

S. epidermidis showed however high resistance levels to the tested antibiotics (Fosfomycin, Acides fucidiques, Quinolones, Glycoproteins, Macrolides, Rifamycin and B-Lactamines) (Table 5). The advantage of natural antibiotics (plants extract), is that they don't push the microbes to develop resistance against them. They are composed of many different molecules so that the microbe needs to synthesize many enzymes to be able to neutralize all of these (Candan et al., 2003) 
Table-4. Antibiogram results of Pseudomonas aeruginosa

\begin{tabular}{|c|c|}
\hline Antibiotics & Pseudomonas aeruginosa \\
\hline ATM & S \\
\hline CAZ & $\mathrm{S}$ \\
\hline PIP & $\mathrm{R}$ \\
\hline IMP & $\mathrm{S}$ \\
\hline TIC & $\mathrm{R}$ \\
\hline TCC & $\mathrm{R}$ \\
\hline FA & $\mathrm{R}$ \\
\hline $\mathrm{AK}$ & $\mathrm{S}$ \\
\hline GN & $\mathrm{R}$ \\
\hline TOB & $\mathrm{R}$ \\
\hline CIP & $\mathrm{R}$ \\
\hline LVX & $\mathrm{R}$ \\
\hline $\mathrm{CT}$ & $\mathrm{S}$ \\
\hline FOS & $\mathrm{R}$ \\
\hline DO & $\mathrm{R}$ \\
\hline En-BuOH & ++ \\
\hline EEA & + \\
\hline EDCM & + \\
\hline
\end{tabular}

S: sensitive, R: resistant (CA-SFM, 2012); + : sensitive $(9-14 \mathrm{~mm}),++$ : very sensitive (15 -19 $\mathrm{mm})$ (Moreira et al., 2005).

Table-5. Antibiogram results of Staphylococcus strains

\begin{tabular}{|l|c|c|c|}
\hline Antibiotics & $\begin{array}{c}\text { Staphylococcus } \\
\text { aureus } \\
\text { ATCC29213 }\end{array}$ & $\begin{array}{c}\text { Staphylococcus } \\
\text { aureus }\end{array}$ & $\begin{array}{c}\text { Staphylococcus } \\
\text { epidermidis }\end{array}$ \\
\hline FOX & $\mathrm{S}$ & $\mathrm{R}$ & $\mathrm{R}$ \\
\hline OX1 & $\mathrm{S}$ & $\mathrm{R}$ & $\mathrm{R}$ \\
\hline P & $\mathrm{R}$ & $\mathrm{R}$ & $\mathrm{R}$ \\
\hline TET & $\mathrm{S}$ & $\mathrm{S}$ & $\mathrm{S}$ \\
\hline E & $\mathrm{S}$ & $\mathrm{R}$ & $\mathrm{R}$ \\
\hline L & $\mathrm{S}$ & $\mathrm{S}$ & $\mathrm{S}$ \\
\hline VA & $\mathrm{S}$ & $\mathrm{S}$ & $\mathrm{S}$ \\
\hline SP & $\mathrm{S}$ & $\mathrm{S}$ & $\mathrm{S}$ \\
\hline TEC & $\mathrm{S}$ & $\mathrm{S}$ & $\mathrm{S}$ \\
\hline GEN & $\mathrm{S}$ & $\mathrm{S}$ & $\mathrm{R}$ \\
\hline OFX & $\mathrm{S}$ & $\mathrm{S}$ & $\mathrm{R}$ \\
\hline C & $\mathrm{S}$ & $\mathrm{S}$ & $\mathrm{S}$ \\
\hline FA & $\mathrm{S}$ & $\mathrm{S}$ & $\mathrm{R}$ \\
\hline FOS & $\mathrm{S}$ & $\mathrm{S}$ & $\mathrm{R}$ \\
\hline En-BuOH & +++ & +++ & +++ \\
\hline EEA & +++ & +++ & +++ \\
\hline EDCM & +++ & +++ & +++ \\
\hline S & & $\mathrm{S}$ & $2012 ;++$ \\
\hline
\end{tabular}

S: sensitive, R: resistant (CA-SFM, 2012); +++: extremely sensitive (>20 mm) (Moreira et al., 2005).

\section{Minimal inhibitory concentration (MIC)}

The method of dilution in liquid medium was used to confirm quantitatively the previously obtained results. It was found that En-BuOH inhibited the growth of Morganilla morganii, Escherichia coli ATCC25922 and Staphylococcus aureus ATCC29213 with a low concentration $(0.12 \mathrm{mg} / \mathrm{ml}), \quad$ followed by Staphylococcus aureus $(7.8 \mathrm{mg} / \mathrm{ml})$ and Enterobacter colacae $(15.6 \mathrm{mg} / \mathrm{ml})$ (Table 6). It inhibited however the growth of Staphylococcus epidermidis with a high concentration $(125 \mathrm{mg} / \mathrm{ml})$. The ethyl acetate extract (EAE) was characterised by a weak inhibitory concentration against Proteus mirabilis and Morganilla morganii $(0.12 \mathrm{mg} / \mathrm{ml}$ for each) followed by Enterobacter cloacae $(0.98 \mathrm{mg} / \mathrm{ml})$ and Staphylococus epidermidis $(3.9 \mathrm{mg} / \mathrm{ml})$. The lowest minimal inhibitory concentration of the Dichloromethan extract (EDCM) was recorded with Morganilla morganii $(0.12 \mathrm{mg} / \mathrm{ml})$ and Staphylococcus epidermidis $(3.9 \mathrm{mg} / \mathrm{ml})$. High inhibitory concentrations were recorded with Enterobacter aerogenes $(62.5 \mathrm{mg} / \mathrm{ml})$, Escherichia coli, Staphylococcus aureus, and Enterobacter aerogenes $(>250 \mathrm{mg} / \mathrm{ml})$. Our results are partially in contradictory with those of Lairini et al. (2014) who reported weak inhibitory concentration of his aqueous extract against Escherichia coli $(0.31 \mathrm{mg} / \mathrm{ml})$. The minimal inhibitory concentration of the three extracts are superior than that of the methanolic extract used by Belaidi (2012). The minimal inhibitory concentration of En-BuOH and EDCM against Pseudomonas aeruginosa was less than that recorded by Naziri et al. (2012). The inhibition of Staphyloccus aureus needs high concentrations in comparison with the aqueous extract of Lairini et al. (2014) as well as of the methanolic extract of Naziri et al. (2012). The level of sensitivity of the tested strains to different Pomegranate peel extracts differs according to the type of active compounds in each extract and the type of strain (Ozçelik et al., 2011; Su et al., 2014). It depends on the capacity of liposoluble molecules to intercalate in the bacterial membranes and to damage them (Candan et al., 2003; El amri et al., 2014). 
Leila Bouneb et al

Table-6: Minimal inhibitory concentration of the three extracts

\begin{tabular}{|c|c|c|c|c|c|c|c|c|c|c|}
\hline Tested strains & 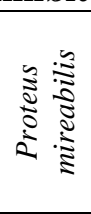 & 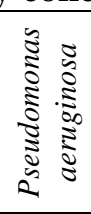 & 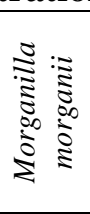 & 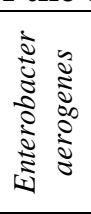 & 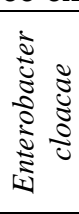 & $\underset{0}{\tilde{0}}$ & 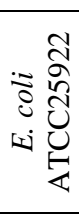 & 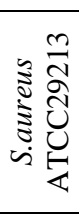 & 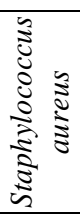 & 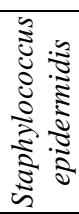 \\
\hline n-butanol(mg/ml) & 15.6 & 31.25 & 0.12 & 62.5 & 15.6 & 125 & 0.12 & 0.12 & 7.8 & 125 \\
\hline Ethyl acetate $(\mathrm{mg} / \mathrm{ml})$ & 0.12 & 250 & 0.12 & 62.5 & 0.98 & 250 & 15.6 & 7.8 & 7.8 & 3.9 \\
\hline \begin{tabular}{|l|}
$\begin{array}{l}\text { dicloromethane } \\
(\mathrm{mg} / \mathrm{ml})\end{array}$ \\
\end{tabular} & 15.6 & 15.6 & 0.12 & $>250$ & 62.5 & $>250$ & 15.6 & 15.6 & 250 & 3.9 \\
\hline
\end{tabular}

\section{Conclusion}

It was concluded from the results of current study that n-Butanol extract of Punica granatum L. peel demonstrated high activity against Gram positive bacteria in comparison with Gram negative bacteria. Our in vitro research confirms the possibility of exploiting pomegranate peels as an alternative or a conjugating treatment of diabetic foot infections, but more experiments are necessary to determine the concentration and the nature of the active molecules in the pomegranate peel.

\section{Acknowledgement}

The authors gratefully thank the members of the laboratory of phytochemistry, physicochemical analysis and biological analysis (The university of Constantine 1, Dr. Agabou and Mr. BELBEKOUCHE from the military hospital Abdelali Benbaatouch (Constantine), Dr. Nabila SOUILAH from the agronomy department and Dr. Imene BECHEKER , the department of sciences of life and of nature, the university of August $20^{\text {th }}, 1955-$ Skikda

Disclaimer: None.

Conflict of Interest: None.

Source of Funding: The project was partially financed by the Directorate General for Scientific Research and Technological Development, Algeria.

\section{References}

Alviano DS and Alviano CS, 2009.Plant extracts: search for new alternatives to treat microbial diseases. Curr. Pharm. Biotechnol. 10(1):106121.

Bagamboula CF, Uyttendaele $\mathrm{M}$ and Debevere $\mathrm{J}$, 2004.Inhibitory effect of thyme and basil essential oils, carvacrol, thymol, estragol, linalool and p- cimene towards Shigella sonnei and S. flexneri. Food Microbiol. 21: 33-42.

Barathikannan K, Venkatadri B, Khusro A, Al-Dhabi NA, Agastian P, Arasu MV, Choi HS and Kim YO, 2016.Chemical analysis of Punica granatum fruit peel and its in vitro and in vivo biological properties. BMC Complement. Altern. Med. 16 : 264. DOI: 10.1186/s12906-016-1237-3.

Belaidi E, 2012, Etude de l'activité antibactérienne des extraits de Berberis Punica granatum (L.) vis - à - vis de souches bactériennes multirésistantes aux antibiotiques isolées du C.H.U de Tlemcen. (Master dissertation). Université de Aboubekr Belkaid, Telemcen.

Boulton AJM, Armstrong DG, Kirsner RS, Attinger CE, Lavery LA, Lipsky BA, Mills JL and Steinberg JS, 2018. Diagnosis and Management of Diabetic Foot Complications. American Diabetes Association. DOI: 10.2337/db20182-14- 23.

Candan F, Unlu M, Tepe B, Daferera D, Polissiou M, Sökemen A and Akpulat HA, 2003. Antioxydant and antimicrobial activity of the essential oil and methanol extracts of Achillea millefolium subsp. millefolium Afan.(Asteraceae). J. Ethnopharmacol. 87: 215,-220.

CA-SFM, 2010. Comité de l'Antibiogramme de la Société Française de Microbiologie CA-SFM. Communiqué 2010. Available from: http://nosobase.chu-

lyon.fr/recommandations/sfm/2010_antibiotiques _casfm.pdf

CA-SFM, 2012. Comite de l'Antibiogramme de la Société Française de Microbiologie. Recommandations 2012. Available from: https://resapath.anses.fr/resapath_uploadfiles/file s/documents/2012\%20ca-sfm.pdf

Citron DM, Goldstein EJ, Merriam CV, Lipsky BA and Abramson MA, 2007. Bacteriology of moderate-to-severe diabetic foot infections and in vitro activity of antimicrobial agents. J. Clin. 
Microbiol. 45: 2819-2828.

El amri J, Elbadaoui K, Zair T, Bouharb H, chakir S and Alaoui T, 2014. Etude de l'activité antibactérienne des huiles essentielles de Teucrium capitatium L et l'extrait de Silene vulgaris sur différentes souches testées. J. Appl. Biosci. 82: 7481-7492.

El-Falleh W, Hannachi H, Tlili Y, Yahia N, Nasri N and Ferchichi A, 2012. Total phenolic contents and antioxidant activities of pomegranate peel, seed, leaf and flower. J. Med. Plants Res. 6: 47244730.

European Committee for Antimicrobial Susceptibility Testing of the European Society of Clinical Microbiology and infectious diseases (EUCAST), 2003. Determination of minimum inhibitory concentrations (MICs) of antimicrobial agents by broth dilution. Clin. Microbiol. Infect. 9(8): 1-7.

Fisher TK, Wolcott R, Wolk DM, Bharara M, Kimbriel HR and Armstrong DG, 2010. Diabetic foot infections: a need for innovative assessments. Int. J. Low Extrem. Wounds. 9: 3136.

Harborne JB, 1998. Phytochemical Methods-A Guide to Modern Techniques of Plant Analysis. 3rd Ed. Chapman and Hall, London. 302p

Houston MC, 2005. Nutraceutical, vitamins, antioxidants and minerals in the prevention and treatment of hypertension. Prog. Cardiovasc. Dis. 47: 396-449.

Khan JA and Hanee S, 2011. Antibacterial properties of Punica granatum peel. Int. J. Appl. Biol. Pharm. 2(3): 23-27.

Kim ND, Mehta R, Yu W, Neeman I, Livney T, Amichay A, Poirier D, Nicholls P, Kirby A, Jiang W, Mansel R, Ramachandran C, Rabi T, Kaplan B and Lansky E, 2002. Chemopreventive and adjuvant therapeutic potential of pomegranate (Punica granatum) for human breast cancer. Breast Cancer Res. Treat. 71(3):203-217. DOI: 10.1023/a:1014405730585

Lairini S, Bouslamti R, Zerrouq F and Farah A, 2014. Valorisation de l'extrait aqueux de l'écorce de fruit de Punica granatum par l'étude de ses activités antimicrobienne et antioxydante (Enhancement of the aqueous extract of the bark of Punica granatum fruit through the study of its antimicrobial and antioxidant activities). J. Mater. Environ. Sci. 5(S1): 2314-2318

Lamri L, Gripiotis E and Ferrario A, 2014. Diabetes in
Algeria and challenges for health policy: a literature review of prevalence, cost,management and outcomes of diabetes and its complications. J. Glob. Health.10:11. DOI:10.1186/1744-8603-1011

Lipsky BA, Aragón-Sánchez J, Diggle M , Embil J, Kono S, Lavery L, Senneville E, Urbančič-Rovan V, Van Asten S, International Working Group on the Diabetic Foot and Peters EJ, 2016. International Working Group on the Diabetic Foot. IWGDF guidance on the diagnosis and management of foot infections in persons with diabetes. Diabet. Metab. Res. Rev. 32(1):45-74. DOI: 10.1002/dmrr.2699.

Lipsky BA, Berendt AR, Cornia PB, Pile JC, Peters EJ, Armstrong DG, Derry HG, Embil JM, Joseph WS, Karchmer AW, Pinzur MS, Senneville E and Infectious Diseases Society of America, 2012. Infectious Diseases Society of America clinical practice guideline for the diagnosis and treatment of diabetic foot infections. Clin. Infect. Dis. 54(12):132-173.

Merghem R, Jay M, Viricel M-R, Bayet C and Voirin B, 1995. Five 8-C benzylated flavonoids from Thymus hirtus (Labiateae). Phytochem. 38(3): 637-640.

Moreira MR, Ponce AG, Del Valle CE and Roura SI, 2005. Inhibitory parameters of essential oils to reduce a foodborne pathogen. LWT. 38(5): 565570.

Naz S, Siddiqi R, Ahmad S, Rasool SA and Sayeed SA, 2007. Antibacterial activity directed isolation of compounds from Punica granatum. J. Food Sci.72:9.M341-M345.

Naziri Z, Rajaian H and Firouzi R, 2012. Antibacterial effects of Iranian native sour and sweet pomegranate (Punica granatum) peel extracts against various pathogenic bacteria. Iran. J. Vet. Res. 13: 282- 288.

Ozçelik B, Kartal M and Orhan I, 2011. Cytotoxicity, antiviral and antimicrobial activities of alkaloids, flavonoids, and phenolic acids. Pharm. Biol. 49(4): 396-402.

Celia MP and Jenifer M, 2018.Antibacterial activity of Punica granatum peel extract against selected ATCC pathogens. Int. J. Appl. Res. 4 (9): 74-77.

Powlson AS and Coll AP, 2010.The treatment of diabetic foot infections. J. Antimicrob Chemother. 65(Suppl 3): iii3-iii9. DOI: 10.1093/jac/dkq299.

Pradeep BV, Manojbabu MK and Palaniswamy M, 2008. Antibacterial activity of Punica granatum 
L. against Gastro Intestinal Tract Infection Causing Organisms. Ethnobot. Leaflets. 12: 10851089.

Rathia P, Rajput CS and Singhal S, 2014. Evaluation of total phenolic contents, antioxidant and antibacterial capacity of aqueous methanolic extracts obtained from Punica granatum peel. Int J Pharm Sci Rev Res. 25:2. 92-424

Reddy MK, Gupta SK, Jacob MR, Khan SI and Ferreira D, 2007. Antioxidant, antimalarial and antimicrobial activities of tannin-rich fractions, ellagitannins and phenolic acids from Punica granatum L. Planta Med. 73(5): 461-467.

Richard JL, Sotto A, Jourdan N, Combescure C, Vannereau D, Rodie M, Lavigne JP and Nîmes University Hospital Working Group on the Diabetic Foot (GP30), 2008. Risk factors and healing impact of multidrug-resistant bacteria in diabetic foot ulcers. Diabet. Metab. 34: 363-369. DOI: 10.1016/j.diabet.2008.02.005

Roberts AD and Simon GL, 2012. Diabetic foot infections: the role of microbiology and antibiotic treatment. Semin. Vasc. Surg. 25: 75-81.

Sajjad W, Sohail M, Ali B, Haq A, Din G, Hayat M, Khan I, Ahmad M and Khan S, 2015.Antibacterial activity of Punica granatum peel extract. Mycopath. 13(2): 105-111

Steel RGD, Torrie JH and Dickery D, 1995. Principles and Procedures of Statistics. A Biomaterial Approach, 3rd Ed. McGraw Hill, New York, USA.

Su Y, Ma L, Wen Y, Wang H and Zhang S, 2014. Studies of the in vitro antibacterial activities of several polyphenols against clinical isolates of methicillin-resistant Staphylococcus aureus. Molecules. 19(8): 12630-12639.

Sultana B, Anwar F, Asi MA and Chatha SAS, 2008. Antioxidant potential of extracts from different agro wastes: Stabilization of corn oil. Grasas.
Aceites. 59: 205-217.

Touhami M, Zennaki A, Bouchetara A, Naceur M, Gharnouti M, Latroch C, Bouziane-Nedjadi K and Boudraa G, 2019. Évolution épidémiologique du diabète de type 1 chez l'enfant : données du registre du département d'Oran, Algérie, 19732017. Epidemiological Evolution of Type 1 Diabetes in Children: Data from the Register of the Department of Oran, Algeria, 1973-2017. Rev. Épidémiol. Santé Publique. 67(6): 369-374.

Vasconcelos LC, Sampaio MC, Sampaio FC and Higino JS, 2003.Use of Punica granatum as an antifungal agent against candidosis associated with denture stomatitis. Mycoses. 46(5-6): 192196.

Voravuthikunchai S, Lortheeranuwat A, Jeeju W, Sririrak T, Phongpaichit S and Supawita T, 2004. Effective medicinal plants against enterohaemorrhagic Escherichia coli O157:H7. J. Ethnopharmacol. 94: 49-55

\section{Contribution of Authors}

Bouneb L: Carried out the identification of the bacterial strains, the extraction of polyphenols and tested the antibacterial activity of the extracts by the method of diffusion on solid medium

Chekroud Z: Supervised the work, wrote the manuscript, discussed the results and corrected the references

Souda I: Carried out the identification of the bacterial strains and determined the minimal inhibitory concentration of the extracts by the method of dilution on solid medium

Ouchenane Z: Carried out the isolation of bacterial strains from diabetic foot 